\title{
HUBUNGAN TINGKAT PENGETAHUAN TENTANG SADARI DENGAN PERILAKU SADARI SEBAGAI DETEKSI DINI KANKER PAYUDARA PADA MAHASISWA D-III KEBIDANAN KHARISMA HUSADA BINJAI TAHUN 2017
}

\author{
Relationship of Knowledge Level of Consciousness With Conscious Behavior as \\ Early Detection of Breast Canceri in Midwifery Diploma Husada \\ Students in Binjai 2017
}

\author{
Ronilda Tambunan ${ }^{1}$ \\ ${ }^{1}$ Dosen Prodi D-III Kebidanan, Akademi Kebidanan Kharisma Husada \\ E-mail: ronildatambunan@gmail.com
}

\begin{abstract}
Abstrak
Kasus kanker payudara di negara berkembang telah mencapai lebih dari 580.000 kasus pada setiap tahunnya 64\% dari jumlah kasus tersebut meninggal karena penyakit ini. Diperkirakan 10 dari 100.000 penduduk Indonesia terkena kanker payudara dan $70 \%$ dari penderita memeriksakan dirinya pada keadaan stadium lanjut. Faktor yang menyebabkan adalah penderita kurang mengerti tentang kanker payudara dan rasa malas serta malu memperlihatkan payudara. Mahasiswi yang menempuh pendidikan dalam bidang kesehatan pada umumnya telah memperoleh pengetahuan tentang SADARI sehingga cenderung membentuk sikap positif yang tercermin dalam perilakunya. Tujuan penelitian ini adalah mengetahui adanya hubungan tingkat pengetahuan tentang SADARI dengan perilaku SADARI. Penelitian ini menggunakan metode observasional analitik dengan pendekatan cross sectional. Teknik sampling yang digunakan adalah simple random sampling dengan subjek penelitian sejumlah 93 mahasiswi yang terdiri dari mahasiswi reguler DIII Kebidanan KHARISMA HUSADA BINJAI semester VI dan VIII. Alat ukur yang digunakan adalah kuesioner dan analisis uji statistik yang digunakan adalah Spearman's Rank dengan bantuan program komputer SPSS versi 17.00.Hasil penelitian dari 93 responden menunjukkan bahwa terdapat responden dengan tingkat pengetahuan tentang SADARI tinggi sejumlah 53 orang (57\%), tingkat pengetahuan tentang SADARI sedang sejumlah 38 orang $(40,8 \%)$ dan tingkat pengetahuan tentang SADARI rendah sejumlah 2 orang $(2,2 \%)$. Sedangkan responden dengan perilaku SADARI yang baik sejumlah 44 orang $(47,3 \%)$, perilaku SADARI yang cukup baik sejumlah $41(44,1 \%)$ dan perilaku SADARI yang kurang baik sejumlah 8 orang $(8,6 \%)$. Hasil uji statistik adalah $\pi=0,404$ dengan signifikansi $0,00(\mathrm{P}<0,05)$.
\end{abstract}

Kata kunci: Pengetahuan, Perilaku, Sadari

\begin{abstract}
Breast cancer cases in developed countries has reached more than 580.000 cases each year and $64 \%$ of these cases died of this disease. An estimated 10 of the Indonesian population of 100.000 are suffered and $70 \%$ of the patients examined her on the advanced stage. Being lazy and embarrassed to show the breast are some factors that cause the patient less understanding about breast cancer. Student who was educated in the health sector in general has gained knowledge about BSE so that tends to establish a positive attitude that is reflected in their behavior. The purpose of this study was to determine the correlation between the knowledge level of BSE and BSE behavior. This research uses an analytic observational study design with cross sectional approach. The sampling technique used is simple random sampling with a number of research subjects consisted of 93 female college students of DIV Midwifery Studies Program of Medical Faculty of UNS in VI and VIII semester. Measuring instruments used are questionnaires and statistical analysis used was Spearman's Rank with the aid of a computer program SPSS version 17.00. The results of the 93 respondents indicated that there were 53 people $(57 \%)$ had a high knowledge level of BSE, 38 people $(40.8 \%)$ had an average knowledge level of BSE and two people (2.2\%) had low knowledge level of BSE. While there were 44 people $(47.3 \%)$ had a good BSE behavior, 41 people $(44.1 \%)$ had a good enough BSE behavior and eight people $(8.6 \%)$ had an unfavorable BSE behavior. The statistical result is $\pi=0.404$ with a significance of 0.00 $(\mathrm{P}<0.05)$.
\end{abstract}

Keywords: Knowledge, Behavior, BSE 


\section{PENDAHULUAN}

Kasus kanker payudara di negara berkembang telah mencapai lebih dari 580.000 kasus pada setiap tahunnya dan kurang lebih 372.000 pasien atau 64\% dari jumlah kasus tersebut meninggal karena penyakit ini. Data WHO (World Health Organization) menunjukkan bahwa $78 \%$ kanker payudara terjadi pada wanita usia 50 tahun ke atas, sedangkan 6\% diantaranya kurang dari 40 tahun. Namun banyak juga wanita yang berusia 30-an menderita penyakit mematikan ini (Suryaningsih, 2009).

Kanker payudara di Indonesia menempati urutan kedua setelah kanker leher rahim. Diperkirakan 10 dari 100.000 penduduk terkena kanker payudara dan $70 \%$ dari penderita memeriksakan dirinya pada keadaan stadium lanjut (Ana, 2007). Beberapa faktor yang menyebabkan hal tersebut adalah penderita tidak tahu atau kurang mengerti tentang kanker payudara, kurang memperhatikan payudara, rasa takut akan operasi, percaya dukun atau tradisional dan rasa malas serta malu memperlihatkan payudara (Sutjipto, 2009).

Dalam perkembangan teknologi dunia kedokteran, ada berbagai macam cara untuk mendeteksi secara dini adanya kelainan pada payudara, diantaranya dengan thermography, mammography, ductography, biopsi dan USG payudara. Disamping itu ada juga cara yang lebih mudah dan efisien untuk dapat mendeteksi kelainan payudara oleh diri sendiri yang dikenal dengan pemeriksaan payudara sendiri (SADARI). Pemeriksaan payudara sendiri (SADARI) merupakan salah satu langkah deteksi dini untuk mencegah terjadinya kanker payudara yang akan lebih efektif jika dilakukan sedini mungkin ketika wanita mencapai usia reproduksi (Suryaningsih, 2009).

Pada usia 20 tahun seorang wanita dianjurkan untuk melakukan pemeriksaan pada payudaranya sendiri setiap bulan atau setiap tiga bulan sekali untuk dapat mendeteksi secara dini jika terdapat kelainan dan segera mendapatkan penanganan yang tepat (Setiati, 2009). Salah satu kelompok yang telah mencapai usia tersebut adalah mahasiswi. Pada saat itu seorang mahasiswi memasuki tahap perkembangan remaja akhir (adolescence) (Sarwono, 2004).

Mahasiswi yang menempuh pendidikan dalam bidang kesehatan pada umumnya telah memperoleh pengetahuan tentang SADARI sehingga akan cenderung membentuk sikap positif yang tercermin dalam perilakunya. Karena adanya pengetahuan tersebut merupakan domain yang sangat penting dalam membentuk tindakan seseorang (Notoatmodjo, 2007).

Pengetahuan merupakan hasil "tahu" dan ini terjadi setelah orang melakukan penginderaan terhadap suatu objek tertentu. Penginderaan terjadi melalui panca indera manusia, yakni indera penglihatan, pendengaran, penciuman, rasa dan raba. Sebagian besar pengetahuan manusia diperoleh melalui mata dan telinga. Pengetahuan merupakan domain yang sangat penting untuk terbentuknya tindakan seseorang.

Berdasarkan pengalaman dan penelitian, perilaku yang didasari oleh pengetahuan akan lebih langgeng daripada perilaku yang tidak didasari oleh pengetahuan (Notoatmodjo, 2007):

1). Tingkatan Pengetahuan

Menurut Notoatmodjo pengetahuan yang tercakup dalam domain kognitif mempunyai 6 tingkat, yaitu : Tahu Cnow dapat diperhatikan sebagai mengingat suatu materi yang telah dipelajari sebelumnya. Termasuk dalam pengetahuan tingkat ini adalah mengingat kembali suatu spesifik dan seluruh bahan yang dipelajari meliputi pengetahuan terhadap fakta, konsep, definisi, nama, peristiwa, tahun, daftar, rumus, teori dan kesimpulan. Oleh karena itu, tahu ini merupakan tingkat pengetahuan yang paling rendah. Kata kerja untuk mengukur bahwa orang tahu tentang apa yang dipelajari antara lain menyebutkan, menguraikan, mendefinisikan, mendatakan dan lain sebagainya.

Memahami (comprehesnsion) diartikan sebagai kemampuan menjelaskan secara benar tentang objek yang diketahui dan dapat mengintepretasikan materi tersebut secara benar. Orang yang telah paham terhadap objek atau materi harus dapat menjelaskan, menyebutkan contoh, 
menyimpulkan, meramalkan dan sebagainya terhadap objek yang dipelajari.

Aplikasi (application) diartikan sebagai kemampuan untuk menggunakan materi yang telah dipelajari pada situasi atau kondisi sebenarnya (real). Aplikasi disini dapat diartikan sebagai penggunaan hukumhukum, rumus, prinsip dan sebagainya dalam konteks lain.

Analisis (analysis) adalah suatu kemampuan untuk menjabarkan materi atau suatu objek ke dalam komponen-komponen tetapi masih dalam suatu struktur organisasi tersebut dan masih ada kaitannya satu sama lain. Kemampuan analisis ini dapat dilihat dari penggunaan kata-kata kerja seperti dapat menggambarkan (membuat bagan), membedakan, memisahkan, mengelompokkan dan sebagainya.

Sintesis (synthesis) menunjukkan pada suatu kemampuan untuk meletakkan atau menghubungkan bagian-bagian di dalam suatu bentuk keseluruhan yang baru atau dengan kata lain sintesis adalah suatu kemampuan untuk menyusun formulasiformulasi yang ada. Misalnya dapat menyusun, dapat merencanakan dan dapat meringkas, dapat menyesuaikan dan sebagainya terhadap suatu teori atau rumusan-rumusan yang telah ada.

Evaluasi (evaluation) berkaitan dengan kemampuan untuk melakukan penilaian terhadap suatu materi atau objek, penilaian didasarkan pada kriteria tertentu.

Metode memperoleh pengetahuan atau method of knowing menurut Purnawan dalam Sulistina (2009) yaitu : Tenacity, yaitu metode memperoleh pengetahuan yang dilakukan dengan sangat meyakini sesuatu, meskipun bisa jadi apa yang diyakininya belum tentu benar. Keyakinan ini disebabkan karena hal yang diyakini tersebut umumnya terjadi. Authority, yaitu metode memperoleh pengetahuan dengan mempercayakan pada pihak yang dianggap kompeten Apriory, yaitu metode memperoleh pengetahuan dengan menitik beratkan pada kemampuan nalar dan intuisi diri sendiri, tanpa mempertimbangkan informasi dari pihak luar. Science, yaitu cara memperoleh pengetahuan dengan melakukan serangkaian cara-cara ilmiah, seperti mengajukan dugaan, pengontrolan variabel, sampai penyimpulan. Cara ini dianggap sebagai cara yang paling dapat diyakini kebenarannya atas pengetahuan yang diperoleh. Hal ini karena pada science telah dilakukan serangkaian uji coba sebelum akhirnya memperoleh pengetahuan berupa kesimpulan dimana pengujianpengujian seperti ini tidak ditemukan pada ketiga metode sebelumnya.

Faktor-faktor yang mempengaruhi pengetahuan Menurut Hana dalam Sulistina (2009) tingkat pengetahuan seseorang dipengaruhi oleh: Pendidikan adalah suatu usaha untuk mengembangkan kepribadian dan kemampuan di dalam dan di luar sekolah serta berlangsung seumur hidup. Pendidikan mempengaruhi proses belajar, semakin tinggi pendidikan seseorang, semakin mudah orang tersebut menerima informasi.

Pengalaman belajar dalam bekerja yang dikembangkan memberikan pengetahuan dan ketrampilan professional serta pengalaman belajar selama bekerja akan dapat mengembangkan kemampuan mengambil keputusan yang merupakan manifestasi dari keterpaduan menalar secara ilmiah dan etik yang bertolak dari masalah nyata dalam bidang keperawatan.

Semakin tua usia semakin bijaksana karena semakin banyak informasi yang dijumpai dan semakin banyak hal yang dikerjakan sehingga menambah pengetahuannya. Pada orang yang sudah tua, tidak dapat diajarkan kepandaian baru kepadanya karena telah mengalami kemunduran baik fisik maupun mental.

Menurut Skinner, seorang ahli psikologi dalam Notoatmodjo (2007) merumuskan bahwa perilaku merupakan reaksi seseorang terhadap stimulus (rangsangan dari luar), maka teori Skinner ini disebut teori : $\mathrm{S}-\mathrm{O}$ - $\mathrm{R}$ atau Stimulus - Organisme - Respon. Skinner membedakan jenis perilaku menjadi dua bagian, yaitu :

Perilaku alami ( innate behavior ) yaitu perilaku yang dibawa sejak lahir berupa refleks dan insting. Contoh dari perilaku ini adalah gerakan refleks atau spontan ketika tangan terkena panas api, kedipan mata bila kena cahaya yang kuat. Perilaku ini secara otomatis digerakkan tanpa melalui pusat susunan syaraf. Jadi respon akan timbul 
seketika setiap mendapatkan stimulus secara otomatis.

Perilaku operan (operant behavior) adalah perilaku yang dibentuk melalui proses belajar. Jenis perilaku ini dikendalikan oleh pusat syaraf atau kesadaran otak. Pada kaitan ini, setelah stimulus diterima kemudian dilanjutkan ke otak. Jenis perilaku ini lebih dominan dibanding perilaku alami (Sosiawan, 2009).

Menurut Skinner dalam Notoatmodjo (2007) berdasarkan respon, perilaku dapat dibedakan menjadi 2 yaitu :

1. Perilaku tertutup : Respon terhadap stimulus dalam bentuk terselubung. Respon terhadap stimulus ini masih terbatas pada perhatian, persepsi, pengetahuan atau kesadaran dan sikap yang terjadi pada orang yang menerima stimulus tersebut dan belum dapat diamati secara jelas oleh orang lain.

2. Perilaku terbuka : Respon terhadap stimulus dalam bentuk tindakan nyata atau terbuka. Respon terhadap stimulus tersebut sudah jelas dalam bentuk tindakan atau praktik yang dengan mudah dapat diamati atau dilihat oleh orang lain.

Perilaku kesehatan dipengaruhi oleh faktor keturunan dan lingkungan yang bermula dari pemikiran atas dasar pengetahuan hingga pada akhirnya muncul dalam perilaku (Purwanto, 2009).

Menurut Skinner dalam Notoatmodjo (2007), klasifikasi perilaku kesehatan antara lain : Perilaku pemeliharaan kesehatan (health maintenance) Merupakan perilaku seseorang untuk memelihara atau menjaga kesehatan agar tidak sakit dan usaha penyembuhan ketika sakit. Perilaku pemeliharaan kesehatan terdiri dari 3 aspek:

a. Perilaku pencegahan penyakit dan penyembuhan penyakit bila sakit serta pemulihan kesehatan bila telah sembuh dari penyakit.

b. Perilaku peningkatan kesehatan apabila seseorang dalam keadaan sehat.

c. Perilaku gizi (makanan dan minuman). Makanan dan minuman dapat memeliha ra kesehatan seseorang tetapi sebaliknya makanan dan minuman dapat menjadi penyebab menurunnya derajat kesehatan seseorang bahkan dapat mendatangkan penyakit.
Perilaku pencarian dan penggunaan sistem atau fasilitas pelayanan kesehatan atau perilaku pencarian pengobatan (health seeking behavior). Merupakan upaya atau tindakan seseorang pada saat menderita penyakit dan atau kecelakaan. Perilaku ini dimulai dari mengobati sendiri sampai mencari pengobatan ke luar negeri. Perilaku kesehatan lingkungan Merupakan bagaimana seseorang merespon lingkungan sehingga lingkungan tersebut tidak mempengaruhi kesehatannya. Perilaku kesehatan lingkungan menurut Becker dalam Notoatmodjo (2007) diklasifikasikan menjadi :

Perilaku hidup sehat merupakan perilaku yang berkaitan dengan upaya seseorang untuk mempertahankan dan meningkatkan kesehatannya (makan dengan menu seimbang, olahraga teratur, tidak merokok, tidak minum minuman keras dan narkoba, istirahat cukup, mengendalikan stress dan perilaku atau gaya hidup lain yang positif bagi kesehatan).

Perilaku sakit ini mencakup respon seseorang terhadap sakit dan penyakit, persepsinya terhadap sakit, pengetahuan tentang penyebab dan gejala penyakit serta pengobatan penyakit. Perilaku peran sakit Perilaku ini meliputi tindakan untuk memperoleh kesembuhan, mengenal(mengetahui) fasilitas atau sarana pelayanan penyembuhan penyakit yang layak, mengetahui hak (memperoleh perawatan dan pelayanan kesehaan) dan kewajiban orang sakit (memberitahukan penyakitnya kepada orang lain terutama dokter atau petugas kesehatan dan tidak menularkan penyakitnya kepada orang lain).

Camenius dalam Sarwono (2004) mengemukakan teori pendidikan yang berwawasan perkembangan, menganjurkan pembagian sekolah berdasarkan teori perkembangan jiwa yang didasarkan pada teori Psikologi Fakultas meliputi :

a. 0-6 tahun : pendidikan oleh ibu sendiri (mother school) untuk mengembangkan bagian dari jiwa (fakultas) penginderaan dan pengamatan

b. 6-12 tahun : pendidikan dasar (elementary school) sesuai dengan berkembangnya fakultas ingatan 
(memory) dan diberikanlah dalam tahap ini pelajaran-pelajaran bahasa, kebiasaan-kebiasaan sosial dan agama.

c. 12-18 tahun : sekolah lanjutan (latin school) sesuai dengan berkembangnya fakultas penalaran (reasoning). Pada tahap ini anak-anak dilatih untuk mengerti prinsip-prinsip kausalitas (hubungan sebab akibat) melalui pelajaran tata bahasa, ilmu alam, matematika, etika, dialektika dan rethorika.

d. 18-24 tahun: pendidikan tinggi (universitas) dan pengembaraan (travel) untuk mengembangkan fakultas kehendak (faculty of will).

Menurut Blos dalam Sarwono (2004) tahap remaja akhir ini juga merupakan masa konsolidasi menuju dewasa yang ditandai dengan beberapa hal, yaitu:

a. Minat yang makin mantap terhadap fungsi-fungsi intelek.Egonya mencari kesempatan untuk bersatu dengan orang-orang lain dalam pengalamanpengalaman baru.

b. Terbentuknya identitas seksual yang tidak akan berubah lagi.

c. Egosentrisme (terlalu memusatkan perhatian pada diri sendiri) diganti dengan keseimbangan antara kepentingan diri sendiri dan orang lain.

Menurut Wiknjosastro (2006) kanker payudara disebut juga Carcinoma Mammae adalah tumor ganas yang tumbuh di dalam jaringan payudara. Tumor ini dapat tumbuh dalam kelenjar payudara, saluran payudara, jaringan lemak maupun jaringan ikat pada payudara. Kanker ini memang tidak tumbuh dengan cepat namun berbahaya. (Suryaningsih, 2009).

Belum diketahui secara pasti penyebab dari kanker payudara ini. Hal yang perlu diketahui bahwa insiden kanker payudara ini meningkat seiring dengan pertambahan usia (Varney, 2004).

Terdapat beberapa faktor risiko yang mampu memicu terjadinya kanker payudara diantaranya :

1. Faktor kesehatan reproduksi meliputi nuliparitas, menarche pada usia muda, menopause pada usia lebih tua, kehamilan pertama pada usia tua (lebih dari 30 tahun) atau tidak mempunyai anak sama sekali dan bertambahnya usia.

2. Pemakaian hormone

3. Kegemukan (lemak berlebih)

4. Terpapar radiasi

5. Riwayat keluarga (anak perempuan yang ibunya menderita kanker payudara memiliki peningkatan risiko terkena kanker payudara)

6. Ras

7. Gaya hidup meliputi merokok, konsumsi alkohol dan malas bergerak (Suryaningsih, 2009)

8. Tanda dan gejala : Hampir $90 \%$ keabnormalan pada payudara ditemukan oleh penderita sendiri, sedangkan $10 \%$ ditemukan melalui pemeriksaan fisik atas sebab tertentu. Sebagian besar atau sebanyak 66\% temuan awal yang dijumpai pada kasus kanker payudara adalah terabanya benjolan yang masih bersifat invasi lokal, kemudian sekitar $11 \%$ muncul tanda rasa nyeri pada jaringan payudara, terjadi nipple discharge sebanyak 9\%, terjadi local edema sebanyak 4\%, dan terjadi nipple retraction sebanyak 3\%. Gejala lanjut yang terjadi meliputi munculnya ulcerasi pada payudara yang menimbulkan rasa gatal, nyeri, pelebaran, kemerahan, atau axillary adenopathy (Pernoll, 2001).

Tingkatan atau Klasifikasi Kanker Payudara

1. Klasifikasi patologik meliputi kanker puting payudara, kanker ductus lactiferous dan kanker dari lobules.

2. Klasifikasi klinik meliputi 4 stadium, sebagai berikut :

a. I merupakan kanker payudara dengan besar sampai $2 \mathrm{~cm}$ dan tidak memiliki anak sebar.

b. II (A dan B), merupakan kanker payudara yang besarnya sampai 2 $\mathrm{cm}$ atau lebih dengan memiliki anak sebar di kelenjar ketiak.

c. III (A, B dan C), merupakan kanker payudara yang besarnya sampai 2 $\mathrm{cm}$ atau lebih dengan anak sebar di kelenjar ketiak, infra dan supraklavikular, infiltrasi ke fasia pektoralis atau ke kulit atau kanker 
payudara yang apert (memecah ke kulit).

d. IV merupakan kanker payudara dengan metastasis yang sudah jauh, misalnya ke tengkorak, tulang punggung, paru-paru, hati atau panggul (Wiknjosastro, 2006)

Disamping itu ada pula penggunaan klasifikasi dengan sistem $\mathrm{T}, \mathrm{N}$, dan $\mathrm{M}$. T berarti tumor size, $\mathrm{N}$ berarti node atau kelenjar get bening regional dan $\mathrm{M}$ berarti metastase atau penyebaran jauh.

Mengajarkan wanita bagaimana melakukan pemeriksaan payudara mandiri adalah bagian yang tidak terpisahkan dalam pelaksanaan pemeriksaan payudara. Pentingnya pemeriksaan payudara tahunan oleh dokter atau tenaga kesehatan dan pemeriksaan bulanan secara mandiri harus ditanamkan pada wanita selama kehidupannya (Varney, 2004).

Dalam mendeteksi kanker payudara secara dini dapat dilakukan dengan berbagai macam cara diantaranya dengan thermography (prosedur diagnosis dengan prinsip berdasarkan level kimia dan aktivitas pembuluh darah yang akan menghasilkan peningkatan suhu pada payudara), mammography (metode pendeskripsian dengan menggunakan sinar $\mathrm{X}$ berkadar rendah), ductography (bagian dari mammography yang berguna untuk mendiagnosis nipple discharge dan intraductal papilloma), biopsi dan USG payudara. Salah satu cara yang lebih mudah dan efisien untuk dapat mendeteksi kelainan payudara oleh diri sendiri adalah dengan pemeriksaan payudara sendiri (SADARI) atau biasa disebut dengan Breast Self Examination

$(B S E)$. SADARI ini penting untuk dilakukan karena $85 \%$ penderita kanker menemukan kanker payudaranya sendiri. Berikut merupakan langkah-langkah pada SADARI :

1. Melihat : Meliputi bentuk dan ukuran, puting lurus ke depan atau tertarik ke dalam, puting atau kulit ada yang lecet atau tidak, warna kulit tampak kemerahan atau tidak, tekstur kulit tampak menebal dengan pori-pori melebar atau mulus, tampak adanya kerutan, cekungan atau tidak (payudara yang normal adalah payudara dengan bentuk sempurna tanpa perubahan warna, tekstur dan pembengkakan

2. Memijat : Secara lembut pijat payudara dari tepi hingga ke puting, untuk mengetahui ada atau tidaknya cairan yang keluar dari puting susu (seharusnya tidak ada cairan yang keluar, kecuali sedang menyusui).

3. Merab : Dilakukan dengan gerakan memutar mulai dari tepi payudara hingga ke puting, masing-masing gerakan memutar dilakukan dengan kekuatan tekanan berbeda-beda, yaitu:

a. tekanan ringan untuk meraba ada tidaknya benjolan di dekat permukaan kulit.

b. tekanan sedang untuk meraba ada tidaknya benjolan di tengah-tengah jaringan payudara

c. tekanan cukup kuat untuk merasakan adanya benjolan di dasar payudara, dekat dengan tulang dada

d. Meraba ketiak : Raba ketiak dan area di sekitar payudara untuk mengetahui ada tidaknya benjolan (Suryaningsih, 2009).

Hubungan antara tingkat pengetahuan SADARI dengan perilaku SADARI pada mahasiswi. Berdasarkan penjabaran tinjauan pustaka diatas dapat dikatakan bahwa dengan adanya tingkat pengetahuan yang dimiliki tentang pemeriksaan payudara sendiri (SADARI) akan membentuk kecenderungan sikap positif yang tercermin dalam perilakunya. Hal ini didukung oleh pernyataan bahwa pengetahuan merupakan domain yang sangat penting untuk terbent uknya tindakan seseorang dan perilaku yang didasarkan oleh pengetahuan akan lebih langgeng daripada tidak didasari oleh pengetahuan (Notoatmodjo, 2007). SADARI ini dirasa perlu dan efektif untuk dilakukan pada tahap remaja akhir atau kelompok usia perguruan tinggi (17-24 tahun) karena pada batasan usia tersebut (20 tahun lebih tepatnya) merupakan saat yang tepat untuk mulai melakukan usaha preventif deteksi dini terjadinya penyakit kanker payudara, terutama pada kelompok yang berhubungan dengan dunia atau pendidikan kesehatan yang nantinya akan 
mengaplikasikannya kepada masyarakat luas.

\section{BAHAN DAN METODE}

Lokasi penelitian ini dilakukan di Akademi Kebidanan Kharisma Husada Binjai Tahun 2017, dengan alasan berdasarkan survei awal ternyata ada hubungan tingkat pengetahuan tentang sadari dengan perilaku sadari sebagai deteksi dini kanker payudara pada mahasiswa D-III Kebidanan Kharisma Husada Binjai. Penelitian ini dilaksanakan mulai bulan Juli - Desember 2017.

Populasi adalah seluruh objek penelitian yang diteliti. Populasi pada penelitian ini adalah seluruh mahasiswa Akademi Kebidanan Kharisma Husada Binjai sebanyak 93 orang.

Sampel adalah sekumpulan data yang diambil atau diseleksi dari suatu populasi. Sampel dari penelitian ini adalah mahasiswa Akademi Kebidanan charisma Husada Binjai Tahun 2017. Sampel dalam penelitian ini adalah 93 responden dengan menggunakan metode total sampling yaitu mengambil seluruh total populasi yang akan dijadikan objek yang diteliti.

Metode pengumpulan data yang digunakan dalam penelitian ini adalah pengumpulan data dengan menggunakan kuesioner. dalam bentuk pertanyaan tertutup yang disajikan dalam bentuk sedemikian rupa sehingga responden hanya memberikan tanda checklist pada kolom ataupun tempat yang disediakan.

Peneliti ingin mengetahui bagaimana hubungan tingkat pengetahuan tentang SADARI dengan perilaku SADARI ini dilakukan pada mahasiswi DIII Kebidanan KHARISMA HUSADA BINJAI Tahun 2017.

HASIL

Tabel 1. Pengetahuan tentang SADARI

\begin{tabular}{ccc}
\hline Tingkat Pengetahuan & Frekuensi & Persentase (\%) \\
\hline Rendah & 2 & 2,2 \\
Sedang & 38 & 40,8 \\
Tinggi & 53 & 57,0 \\
\hline Total & $\mathbf{9 3}$ & $\mathbf{1 0 0 , 0}$ \\
\hline
\end{tabular}

Dari tabel 1 diatas dapat dilihat data kuesioner tingkat pengetahuan tentang SADARI pada mahasiswa DIII Kebidanan Kharisma Husada Binjai diperoleh nilai terendah adalah 25 dan nilai tertinggi adalah 44.

Hasil penelitian ini menunjukkan bahwa sebagian besar responden memiliki tingkat

pengetahuan tentang SADARI yang baik. Responden dengan tingkat pengetahuan tentang SADARI tinggi sejumlah 57\%, tingkat pengetahuan tentang SADARI sedang sejumlah $40,8 \%$ dan tingkat pengetahuan tentang SADARI rendah sejumlah $2,2 \%$.

Tabel 2. Sikap tentang SADARI

\begin{tabular}{ccc}
\hline Perilaku & Frekuensi & Persentase (\%) \\
\hline Kurang baik & 8 & 8,6 \\
Cukup baik & 41 & 44,1 \\
Baik & 44 & 47,3 \\
\hline Total & $\mathbf{9 3}$ & $\mathbf{1 0 0 , 0}$ \\
\hline
\end{tabular}


Berdasarkan Tabel 2 diatas dapat diketahui data kuesioner perilaku SADARI pada mahasiswa DIII Kebidanan Kharisma Husada Binjai diperoleh nilai terendah adalah 14 dan nilai tertinggi adalah 55 .

Dari hasil penelitian diperoleh distribusi perilaku meliputi perilaku SADARI yang baik sejumlah 47,3\%, perilaku SADARI yang cukup baik sejumlah $44,1 \%$ dan perilaku SADARI yang kurang baik sejumlah $8,6 \%$.

Perilaku SADARI sebagai deteksi dini kanker payudara ini mencakup aktivitas, waktu dan teknik dalam melakukan SADARI.

Tabel 3. Perilaku tentang SADARI

\begin{tabular}{ccc}
\hline Pertanyaan & Frekuensi & Persentase (\%) \\
\hline Selalu & 4 & 4,30 \\
Sering & 14 & 15,05 \\
Kadang & 67 & 72,04 \\
Tidak pernah & 8 & 8,60 \\
\hline Total & $\mathbf{9 3}$ & $\mathbf{1 0 0 , 0 0}$ \\
\hline
\end{tabular}

Dari hasil penelitian pada 93 responden diketahui bahwa sejumlah $4,3 \%$ responden selalu melakukan SADARI, 15,05\% responden sering melakukan SADARI, 72,05\% responden kadang melakukan SADARI dan $8,6 \%$ responden tidak melakukan SADARI.

Tabel 4. Item pertanyaan tentang tujuan melakukan SADARI

\begin{tabular}{ccc}
\hline Pertanyaan & Frekuensi & Persentase (\%) \\
\hline Selalu & 17 & 18,28 \\
Sering & 26 & 27,96 \\
Kadang & 45 & 48,38 \\
Tidak pernah & 5 & 5,38 \\
\hline Total & $\mathbf{9 3}$ & $\mathbf{1 0 0 , 0 0}$ \\
\hline
\end{tabular}

Dari hasil penelitian pada 93 responden diketahui bahwa sejumlah $18,28 \%$ responden selalu melakukan SADARI sebagai deteksi dini kanker payudara, $27,96 \%$ responden sering melakukan SADARI sebagai deteksi dini kanker payudara, $48,38 \%$ responden kadang melakukan SADARI sebagai deteksi dini kanker payudara dan 5,38\% diantaranya tidak melakukan SADARI sebagai deteksi dini kanker payudara.

Tabel 5. Item pertanyaan tentang malas tidaknya melakukan SADARI

\begin{tabular}{lcc}
\hline \multicolumn{1}{c}{ Pertanyaan } & Frekuensi & Persentase (\%) \\
\hline Selalu & 6 & 6,45 \\
Sering & 11 & 11,83 \\
Kadang & 60 & 64,51 \\
Tidak pernah & 16 & 17,21 \\
\multicolumn{1}{r}{ Total } & $\mathbf{9 3}$ & $\mathbf{1 0 0 , 0 0}$ \\
\hline
\end{tabular}

Dari hasil penelitian pada 93 responden diketahui bahwa sejumlah $6,45 \%$ responden selalu merasa malas untuk melakukan SADARI, $11,83 \%$ responden sering merasa malas untuk melakukan SADARI, 64,51\% responden kadang merasa malas untuk melakukan SADARI dan 17,21\% diantaranya tidak pernah merasa malas untuk melakukan SADARI. 
Tabel 6. Item pertanyaan tentang malu tidaknya melakukan SADARI

\begin{tabular}{ccc}
\hline Pertanyaan & Frekuensi & Persentase (\%) \\
\hline Selalu & 2 & 2,15 \\
Sering & 4 & 4,30 \\
Kadang & 14 & 15,05 \\
Tidak pernah & 73 & 78,50 \\
\hline Total & $\mathbf{9 3}$ & $\mathbf{1 0 0 , 0 0}$ \\
\hline
\end{tabular}

Dari hasil penelitian pada 93 responden responden kadang merasa malu untuk diketahui bahwa sejumlah $2,15 \%$ responden melakukan SADARI dan 78,50\% diantaranya selalu merasa malu untuk melakukan tidak pernah merasa malu untuk melakukan SADARI, $4,30 \%$ responden sering merasa SADARI. malu untuk melakukan SADARI, $15,05 \%$

Tabel 7. Item pertanyaan tentang frekuensi melakukan SADARI

\begin{tabular}{lcc}
\hline \multicolumn{1}{c}{ Pertanyaan } & Frekuensi & Persentase (\%) \\
\hline Selalu & 12 & 12,91 \\
Sering & 18 & 19,35 \\
Kadang & 49 & 52,69 \\
Tidak pernah & 14 & 15,05 \\
\hline \multicolumn{1}{c}{ Total } & $\mathbf{9 3}$ & $\mathbf{1 0 0 , 0 0}$ \\
\hline
\end{tabular}

Dari hasil penelitian pada 93 responden diketahui bahwa sejumlah $12,91 \%$ responden selalu melakukan SADARI minimal satu kali dalam satu bulan, $19,35 \%$ responden sering melakukan SADARI minimal satu kali dalam satu bulan, 52,69\% responden kadang melakukan SADARI minimal satu kali dalam satu bulan dan $15,05 \%$ diantaranya tidak pernah melakukan SADARI minimal satu kali dalam satu bulan.

Tabel 8. Item pertanyaan tentang waktu melakukan SADARI

\begin{tabular}{ccc}
\hline Pertanyaan & Frekuensi & Persentase $(\%)$ \\
\hline Selalu & 13 & 13,98 \\
Sering & 16 & 17,20 \\
Kadang & 43 & 46,24 \\
Tidak pernah & 21 & 22,58 \\
\hline Total & $\mathbf{9 3}$ & $\mathbf{1 0 0 , 0 0}$ \\
\hline
\end{tabular}

Dari hasil penelitian pada 93 responden diketahui bahwa sejumlah $13,98 \%$ responden selalu melakukan SADARI sekitar satu minggu setelah haid, 17,20\% responden sering melakukan SADARI sekitar satu minggu setelah haid, 46,24\% responden kadang melakukan SADARI sekitar satu minggu setelah haid dan $22,58 \%$ diantaranya tidak pernah melakukan SADARI minimal satu kali dalam satu bula sekitar satu minggu setelah haid.

\section{PEMBAHASAN}

Semua responden merupakan mahasiswi DIII Kebidanan yang sebagian besar memiliki tingkat pengetahuan yang baik mengenai kanker payudara dan SADARI. Hal ini sesuai dengan teori yang menyebutkan bahwa tingkat pendidikan yang ditempuh oleh individu merupakan salah satu faktor yang akan mendukung kemampuannya untuk menerima informasi, seperti yang dituliskan oleh Utami (2007) bahwa semakin tinggi tingkat pendidikan seseorang maka makin luas pula cara pandang dan cara pikirnya dalam menghadapi suatu keadaan yang terjadi di sekitarnya.

Rentang usia mahasiswi yang menjadi responden dalam penelitian ini adalah 20-23 tahun. Sesuai dengan Varney (2004) yang mengungkapkan bahwa insiden kanker payudara meningkat seiring dengan 
pertambahan usia, maka dari itu kesadaran akan pentingnya upaya perilaku SADARI sebagai upaya deteksi dini kanker payudara perlu ditingkatkan pula. Hal ini juga sesuai dengan rekomendasi dari American Cancer Society yang menganjurkan bagi wanita yang mulai memasuki usia 20 tahun keatas untuk melakukan pemeriksaan klinik payudara sekurang-kurangnya tiga tahun sekali dan mendapat informasi tentang keuntungan dan keterbatasan SADARI sehingga wanita yang memilih melakukan SADARI dapat melakukan SADARI dengan tepat sesuai dengan pedoman tekniknya (Smith, 2003).

\section{Pengetahuan SADARI}

Hasil penelitian ini menunjukkan bahwa sebagian besar responden memiliki tingkat pengetahuan tentang SADARI yang baik. Hal ini disebabkan karena latar belakang pendidikan responden yaitu mahasiswi kebidanan yang telah mendapatkan informasi atau pengetahuan tentang kanker payudara dan SADARI. Hal ini sesuai dengan Hana dalam Sulistina (2009) yang menyatakan bahwa pengetahuan dan sikap seseorang dipengaruhi oleh beberapa faktor diantaranya pendidikan, pengalaman dan usia.

Pada penelitian juga masih terdapat tingkat pengetahuan tentang SADARI yang rendah. Hal ini bisa disebabkan oleh beberapa hal diantaranya adalah faktor pengalaman yang mempengaruhi pengetahuan seseorang dan tergantung pada ingatan seseorang pada saat pengisian kuesioner. Sesuai dengan Notoatmodjo (2007) yang mengemukakan bahwa pengetahuan terjadi setelah orang melakukan penginderaan terhadap suatu objek tertentu. Penginderaan terjadi melalui panca indera manusia, yakni indera penglihatan, pendengaran, penciuman, rasa dan raba. Penginderaan yang baik akan meningkatkan pemahaman terhadap suatu objek atau informasi. Memahami diartikan sebagai suatu kemampuan untuk menjelaskan secara benar tentang objek yang diketahui dan dapat mengintepretasikan informasi tersebut secara benar. Maka dari itu meskipun responden pernah mendapat informasi tentang kanker payudara dan SADARI tetapi responden tersebut tidak melakukan penginderaan dengan baik, hal ini mengakibatkan pemahaman responden yang kurang baik. Notoatmodjo (2007) juga mengemukakan bahwa kemampuan mengingat seseorang dapat dipengaruhi oleh dimensi waktu.

\section{PERILAKU SADARI}

Menurut Suryaningsih (2009) SADARI merupakan salah satu cara yang lebih mudah dan efisien untuk dapat mendeteksi kelainan payudara oleh diri sendiri. Hal ini sesuai dengan hasil penelitian yang diperoleh bahwa responden kadang melakukan SADARI sebagai deteksi kanker payudara.

Dari hasil penelitian menunjukkan perilaku SADARI yang baik dari responden. Hal ini dibuktikan dengan sebagian besar responden tidak pernah malu melakukan SADARI. Dalam tinjauan teori disebutkan bahwa tingginya angka kematian karena kanker payudara disebabkan sebagian besar penderita datang setelah stadium lanjut. Hal ini disebabkan oleh beberapa faktor diantaranya adalah penderita tidak tahu atau kurang mengerti tentang kanker payudara, kurang memperhatikan payudara, rasa takut akan operasi, percaya dukun atau tradisional dan rasa malas serta malu memperlihatkan payudara (Sutjipto, 2009). Namun, pada hasil penelitian juga diperoleh bahwa sebagian besar responden kadang merasa malas melakukannya.

Varney (2004) mengungkapkan bahwa SADARI dianjurkan untuk dilakukan secara mandiri sekali dalam satu bulan pada saat setelah menstruasi. Hal ini sesuai dengan hasil penelitian yang diperoleh bahwa sebagian responden telah melakukan SADARI sesuai dengan frekuensi dan waktu yang dianjurkan.

Serangkaian langkah yang dilakukan pada SADARI meliputi berdiri di depan cermin dengan mengangkat tangan, melihat bentuk dan ukuran payudara, melihat perubahan warna kulit payudara, memijat hingga puting untuk mengetahui ada tidaknya cairan yang keluar dan meraba seluruh bagian payudara dengan variasi tekanan untuk mengetahui ada tidaknya benjolan serta meraba hingga ketiak (Suryaningsih, 2009). Hal ini sesuai dengan hasil penelitian yang diperoleh bahwa sebagian besar responden selalu melakukan langkah-langkah tersebut ketika melakukan SADARI. 


\section{HASIL ANALISIS}

Setelah dilakukan uji statistik dengan menggunakan Spearman's rank diperoleh hasil koefisien korelasi $\pi=0,404$ dengan tingkat signifikansi $0,00(\mathrm{P}<0,05)$ membuktikan bahwa terdapat hubungan positif antara tingkat pengetahuan tentang SADARI dengan perilaku SADARI. Dari hasil diatas ada kecenderungan semakin tinggi tingkat pengetahuan tentang SADARI maka semakin baik pula perilaku SADARI dan semakin rendah tingkat pengetahuan tentang SADARI maka semakin kurang baik pula perilaku SADARI. Disamping itu masih terdapat beberapa tingkat pengetahuan tentang SADARI yang tinggi tetapi perilaku SADARI yang dilakukan cukup atau bahkan kurang baik.

Berdasarkan hasil penelitian diatas dapat dibuktikan bahwa hipotesis diterima yaitu adanya hubungan antara tingkat pengetahuan tentang SADARI dengan perilaku SADARI. Hal ini sesuai dengan tinjauan teori bahwa perilaku SADARI yang termasuk dalam perilaku kesehatan, dipengaruhi oleh faktor keturunan dan lingkungan yang bermula dari pemikiran atas dasar pengetahuan hingga pada akhirnya muncul dalam perilaku (Purwanto, 2009).

Hasil penelitian diatas juga sesuai dengan tinjauan teori yang menyebutkan bahwa berdasarkan pengalaman dan penelitian, perilaku yang didasari oleh pengetahuan akan lebih langgeng daripada perilaku yang tidak didasari oleh pengetahuan (Notoatmodjo, 2007).

Dari hasil penelitian ini terdapat beberapa perbedaan dengan penelitian sebelumnya karya Utami dengan judul Hubungan antara Pengetahuan tentang Kanker Payudara dengan Perilaku Pemeriksaan Payudara Sendiri (SADARI) pada Mahasiswi Program Studi Ilmu Keperawatan (PSIK) A FK UGM pada tahun 2007. Hasil analisis pada penelitian tersebut diperoleh nilai $\pi=0,176$ dengan tingkat signifikansi $0,064(\mathrm{P}>0,05)$ menunjukkan bahwa tidak ada hubungan yang signifikan antara tingkat pengetahuan tentang kanker payudara dengan perilaku pemeriksaan payudara sendiri (SADARI) dengan tingkat korelasi sangat lemah.

Perbedaan hasil analisis tersebut dapat disebabkan oleh faktor subjek penelitian dengan latar yang berbeda. Subjek penelitian yang digunakan peneliti sebelumnya adalah mahasiswi Stikes Senior Medan sedangkan peneliti disini menggunakan subjek penelitian dari mahasiswi Program Studi DIII Kebidanan Kharisma Husada Binjai. Di samping itu, variabel bebas pada penelitian tersebut adalah pengetahuan tentang kanker payudara yang cakupannya masih terlalu luas, sedangkan peneliti menggunakan variable bebas yang lebih spesifik yaitu pengetahuan tentang SADARI.

\section{KESIMPULAN}

Dari hasil penelitian hubungan antara tingkat pengetahuan tentang SADARI dengan perilaku SADARI sebagai deteksi dini kanker payudara pada mahasiswi DIII Kebidanan Kharisma Husada Binjai, maka diperoleh kesimpulan sebagai berikut:

1. Tingkat Pengetahuan

Tingkat pengetahuan tentang SADARI pada mahasiswi DIII Kebidanan kharisma Husada Binjai sudah baik. Dibuktikan dari hasil penelitian, diperoleh distribusi tingkat pengetahuan tinggi sebanyak $57 \%$, tingkat pengetahuan sedang sebanyak $40,8 \%$ dan tingkat pengetahuan rendah sebanyak $2,2 \%$.

2. Perilaku SADARI

Perilaku Sadari pada mahasiswi DIII Kebidanan Akbid Kharisma Husada Binjai sudah cukup baik. Dibuktikan dari hasil penelitian, diperoleh distribusi perilaku baik sebanyak $47,3 \%$, perilaku cukup baik sebanyak $44,1 \%$ dan perilaku kurang baik sebanyak $8,6 \%$.

Terdapat hubungan positif dan signifikan antara tingkat pengetahuan tentang SADARI dengan perilaku SADARI pada mahasiswi DIII Kebidanan Akademi Kebidanan Kharsima Husada Binjai dengan tingkat korelasi sedang.

\section{SARAN}

Dari kesimpulan hasil penelitian diatas, dapat dikemukakan beberapa saran sebagai berikut :

1. Bagi Profesi

Bidan mampu melanjutkan dan lebih meningkatkan perhatian terhadap pendidikan kesehatan bagi wanita khususnya tentang kanker payudara dan tindakan preventif serta promotif yaitu dengan SADARI.

2. Bagi Institusi

Mengembangkan kurikulum dan meningkatkan peran pendidik dalam menyampaikan pengetahuan tentang kanker 
payudara dan deteksi dini dengan SADARI bagi mahasiswa kebidanan secara lebih menarik sehingga mampu meningkatkan pengetahuan dan ketrampilan dalam mengaplikasikannya.

\section{Bagi Masyarakat}

Meningkatkan tindakan preventif terjadinya kanker payudara secara dini dengan cara meningkatkan pengetahuan tentang kanker payudara dan SADARI serta mampu mengaplikasikannya dalam kehidupan sehari-hari bagi masyarakat.

\section{DAFTAR PUSTAKA}

Notoatmodjo, S. 2005. Metodologi Penelitian Kesehatan. Jakarta : Rineka Cipta. 2007. Promosi Kesehatan dan Ilmu Perilaku. Jakarta : Rineka Cipta

Nursalam. 2003. Konsep dan Penerapan Metodologi Penelitian Ilmu Keperawatan. Jakarta : Salemba Medika Ana, K. 2007. Panduan Lengkap kesehatan Wanita. Yogyakarta : Gala Ilmu Semesta

Arikunto, S. 2006. Prosedur Penelitian Suatu Pendekatan Praktik. Jakarta :Rineka Cipta

Azwar, S. 2007. Penyusunan Skala Psikologi. Yogyakarta : Pustaka Pelajar

Budiarto, E. 2002. Biostatistika Untuk Kedokteran dan Kesehatan Masyarakat. Jakarta : EGC

2003. Metodologi Penelitian Kedokteran. Jakarta : EGC

Cunningham, F. 2008. Williams Gynecology. USA : McGraw Hill Company

Dahlan, M. 2008. Statistik untuk Kedokteran dan Kesehatan. Jakarta : Salemba Medika

Hapsari, E. 2008. Hubungan Tingkat pendidikan Formal dengan Pengetahuan Ibu tentang Pemeriksaan Payudara Sendiri di Desa Wonorejo Polokarto Sukoharjo. Skripsi. Tidak diterbitkan. FK UNS. Surakarta

Juliandi, A. 2009. Validitas dan Reliabilitas http://www.azuarjuliandi.com/openarticles/ validitasreliabilitas.pdf Diakses tanggal 08 Agustus 2017

Pernoll, M. 2001. Obstetrics And Gynecology $10^{\text {th }}$ edition. USA : McGraw Hill Company Purwanto, H. 2009. Pengantar Perilaku Manusia untuk Keperawatan. Jakarta :EGC
Sarwono, S. 2004. Psikologi Remaja. Jakarta : PT. Raja Grafindo Persada Setiati, E. 2009. Waspadai

Smith, R., Saslow, D., Sawyer, K., Burke, W., Costanza, M., et all. 2003.

American Cancer Guidelines For Breast Cancer Screening. A Journal For Clinicians http://caonline.amcanceroc.org/cgi/content/ full/53/3/141 Diakses tanggal 1 September 2017

Sosiawan. 2005. Konsep Manusia dan Perilakunya. http://edwi.dosen.upnyk.ac.id/ PSIKOM.2.05.doc Diakses tanggal 15 September 2017

Sugiyono. 2007. Statistika untuk Penelitian. Bandung : Alfabeta. 2008. Metode Penelitian Pendidikan. Bandung : Alfabeta

Sulistina, D. 2009. Hubungan antara Pengetahuan Menstruasi dengan Perilaku Kesehatan Remaja Putri tentang Menstruasi di SMPN 1 Trenggalek. Skripsi. Tidak diterbitkan. FK UNS. Surakarta

Suryaningsih, E. 2009. Kupas Tuntas Kanker Payudara. Yogjakarta : Paradigma Indonesia.

Sutjipto. 2007. Permasalahan Deteksi Dini dan Pengobatan Kanker Payudara. http://www.dharmais.co.id . Diakses tanggal 15 Agustus 2017

Taufiqurrahman, M. 2008. Pengantar Metodologi Penelitian untuk Ilmu Kesehatan. Surakarta : UNS Press

Utami, N. 2007. Hubungan Tingkat Pengetahuan Kanker Payudara dengan Perilaku Pemeriksaan Payudara Sendiri (SADARI) pada Mahasiswi PSIK A FK UGM. Skripsi. Tidak diterbitkan. FK UGM. Yogyakarta Varney

H. 2004. Ilmu Kebidanan (Varney's midwifery $\left.3^{r} e d\right)$. Bandung : Sekelola publisher

Wardana, T. 2008. Hubungan antara Tingkat Pengetahuan Kesehatan Reproduksi dengan Koitus Pranikah Remaja Penghuni Rumah Kos di Kalurahan Jebres, Kecamatan Jebres, Surakarta. Skripsi. Tidak diterbitkan. FK UNS. Surakarta.

Wiknjosastro, H. 2006. Ilmu Kandungan. Jakarta : Yayasan Bina Pustaka Sarwono Prawirohardjo 